\title{
Het belang van meer openheid over SUDEP
}

Sudden Unexpected Death in Epilepsy (SUDEP) staat wereldwijd meer en meer in de belangstelling. Onderzoek laat zien dat patiënten er graag meer van willen weten en dat er maatregelen zijn om het risico te beperken, zoals een betere therapietrouw, uitbreiding van de behandeling van de epilepsie of meer nachtelijk toezicht. Het is daarom wenselijk dat SUDEP laagdrempelig besproken wordt.

Sudden unexpected death in epilepsy of SUDEP verwijst naar het plots en onverwacht overlijden van iemand met epilepsie bij wie bij obductie geen doodsoorzaak wordt gevonden. SUDEP is de meest voorkomende direct aan epilepsie gerelateerde doodsoorzaak. Naarmate de ernst van de epilepsie toeneemt, neemt ook de incidentie toe. De incidentie kan oplopen van zes tot negen per rooo persoonsjaren. De belangrijkste risicofactoren voor SUDEP zijn het hebben van tonisch-clonische aanvallen en de frequentie van tonisch-clonische aanvallen (Harden et al., 2017). Andere risicofactoren zijn nachtelijke aanvallen, gebruik van meerdere anti-epileptica, verstandelijke beperking en mannelijk geslacht. SUDEP heeft altijd al bestaan maar lange tijd was er nauwelijks aandacht voor. SUDEP Global Conversation, een alliantie van nabestaanden en patiëntenorganisaties, heeft gezorgd voor meer aandacht en meer onderzoek (https://www.sudepglobalconversation.com). Wereldwijd is er nu een tendens te bemerken dat SUDEP actiever in de spreekkamer besproken wordt. Er zijn meerdere redenen waarom meer openheid over SUDEP wenselijk is, zoals uit het volgende zal blijken.

\section{Patiënten willen er graag meer van weten}

Diverse peilingen laten zien dat patiënten er prijs op stellen om te horen over SUDEP (Kroner et al., 20I4; Long et al., 20I8, Cooper et al., 2019). Het merendeel van de patiënten $(7 \mathrm{r} \%)$ zou graag voorlichting willen krijgen over SUDEP ongeacht het risico, $27 \%$ alleen wanneer er sprake is van een verhoogd SUDEP-risico en $2 \%$ in het geheel niet (Kroner et al., 2014). In een andere peiling gaven alle patiënten aan dat voorlichting over SUDEP hun therapietrouw zal bevorderen en zal helpen om de leefstijladviezen in acht te nemen (Long et al., 2018). Op de vraag of SUDEP-informatie de angst voor aanvallen vergroot, gaf slechts een derde van de patiënten aan dat dit het geval was. Interessant genoeg gaven alle patiënten aan (dus ook degenen bij wie voorlichting leidde tot meer angst) dat ze het als hun recht zien om over SUDEP geïnformeerd te worden (Long et al., 2018). Het recht op meer informatie over SUDEP werd in een recente tuchtzaak ook onderkend door het Centraal Tuchtcollege. Dat de meeste patiënten willen weten van SUDEP, betekent nog niet dat iedereen hier even veel over horen wil. Een Amerikaans onderzoek liet zien dat $60 \%$ van de respondenten behoefte had aan gedetailleerde informatie; $32 \%$ aan basale informatie en $8 \%$ geen behoefte had aan SUDEPinformatie (Xu et al., 2015). Het is daarom belangrijk dat de hoeveelheid informatie aansluit bij de individuele behoefte.

\section{Samen beslissen}

De arts-patiënt relatie verandert. Het beeld dat de arts de informatie actief filtert en vertelt wat er gaat gebeuren is achterhaald. De arts-patiënt relatie is veel gelijkwaardiger geworden met meer aandacht voor het uitwisselen van informatie en gezamenlijke besluitvorming. 'Samen beslissen' betekent dat het consult zich richt op het uitwisselen van de mogelijkheden, de medische voor- en nadelen hiervan en het vertalen van deze informatie naar iemands persoonlijke situatie en voorkeuren.

Vroeger waren patiënten voor hun medische informatie afhankelijk van hun arts, maar dat is niet meer het geval. Een onderzoek met Google zoektermen naar epilepsie toonde een exponentiële groei van SUDEP-informatie (Brigo et al., 20I4). In een Duits onderzoek bleek dat bijna alle patiënten die van SUDEP wisten, dit niet van hun neuroloog gehoord hadden maar op een andere manier aan deze informatie gekomen waren (internet, folder of lotgenotencontact) (Surges et al., 2018). Het is wenselijk dat het SUDEP-verhaal in de spreekkamer gedeeld wordt, zodat deze informatie in het juiste perspectief geplaatst wordt. 


\section{Het risico is beïnvloedbaar}

Het argument dat een patiënt geen invloed heeft op zijn SUDEP-risico klopt niet. Er zijn meer en meer aanwijzingen dat het risico van SUDEP afneemt bij intensievere behandeling van de epilepsie, dat wil zeggen tijdig starten van medicatie, toevoegen van extra medicatie, epilepsiechirurgie, nervus vagus stimulatie, diepe hersenstimulatie of het intensiveren van nachtelijk toezicht (Thijs et al., 2019). Al deze stappen kunnen ook nadelen hebben: extra medicatie kan bijwerkingen geven, operaties kunnen gepaard gaan met complicaties etc. Het is belangrijk dat het risico van SUDEP wordt meegenomen in de overweging van de voor- en nadelen van elke nieuwe behandelstap. SUDEP kan bijvoorbeeld een zwaarwegend argument zijn om medicatie te starten, bijvoorbeeld in het geval van een alleenstaande man met incidentele nachtelijke tonischclonische aanvallen. De impact van de aanvallen kan voor hem heel beperkt zijn: de aanvallen doen zich zelden voor, er is geen rijrestrictie etc. De impact van het starten van medicatie om die aanvallen te voorkomen lijkt op het eerste gezicht veel groter: het geeft bijwerkingen, dag-indag-uit medicatie slikken werkt stigmatiserend en vergt discipline. Informatie over SUDEP kan tot gevolg hebben dat hij anders gaat nadenken over de afweging om wel of niet te starten met medicatie. Als hij voor medicatie zou kiezen, kan de informatie over SUDEP de therapietrouw bevorderen. Ook kan dit invloed hebben op de praktijkvoering, bijvoorbeeld sneller contact opnemen met de behandelaar bij ontregeling van aanvallen.

\section{De richtlijn en de praktijk}

De Nederlandse Vereniging voor Neurologie (NVN) heeft een richtlijn opgesteld over hoe om te gaan met voorlichting over SUDEP. SUDEP hoort deel uit te maken van de voorlichting over epilepsie, als de kans op SUDEP is verhoogd, bijvoorbeeld in geval van tonisch-clonische aanvallen. De richtlijn is daarmee op te vatten als 'ja tenzij'. De NVN-richtlijn gaat uit van de eigen beslissingsruimte van de arts bij patiënten met een laag risico. In dat geval kan de arts de afweging maken dit niet te vertellen als de omstandigheden dit toelaten of daartoe nopen. De aanbeveling in de richtlijn komt nog niet overeen met de praktijk: de meeste neurologen geven geen of zelden informatie over SUDEP. Dit is niet alleen in Nederland maar ook in de omliggende landen het geval (Cooper et al., 2019). Belangrijke redenen hiervoor zijn het gebrek aan kennis over SUDEP, het ontbreken van goed voorlichtingsmateri- aal en mogelijk ook het gevoel bij behandelaars dat er weinig interventies zijn om SUDEP te voorkomen.

\section{Tot slot}

Het is wenselijk dat er meer openheid komt over SUDEP.

Voorlichting kan therapietrouw bevorderen en kan een aanmoediging zijn voor het verbeteren van de leefstijl. Daarnaast kan het als argument dienen om patiënten contact op te laten nemen bij aanvalsontregeling. Er is online een patiëntenfolder van het Epilepsiefonds over SUDEP beschikbaar, die te bestellen is via de website www.epilepsie.nl. Een keuzehulpkaart zal in de loop van het jaar ontwikkeld worden en dienen als handvat voor de voorlichtingspraktijk.

\section{Referenties}

Brigo F, Igwe SC, Ausserer H, Nardone R, Tezzon F,

Bongiovanni LG, Trinka E (20I4) Why do people Google epilepsy? An infodemiological study of online behaviour for epilepsy-related search terms. Epilepsy \& Behaviour 31 (2014) 67-70.

Cooper K et al. (2019) Discussing sudden unexpected death in epilepsy with children and young people with epilepsy and their parents/carers: A mixed methods systematic review. Seizure. 2019 Oct 13.

pii: S1059-1311(19)30137-2.

Harden C, Tomson T, Gloss D et al. (2017) Practice guideline summary: Sudden unexpected death in epilepsy incidence rates and risk factors. Neurology, 88, 1674-1680.

Long L, Citterman-Hart S, Shelby J (2018) To reveal of conceal? Adult patient perspectives on SUDEP disclosure. Epilepsia Behaviour: 79-84.

Kroner BL, Wright C, Friedman D, Macher K, Preiss L, Misajon J, Devinsky O (2014) Characteristics of epilepsy patients and caregivers who either have or have not heard of SUDEP. Epilepsia 55(10):1486-94. Surges R, von Wrede R, Porschen T, Elger CE (2018) Knowledge of sudden unexpected death in epilepsy (SUDEP) among 372 patients attending a German tertiary epilepsy center Epilepsy \& Behav: 360-364.

Tuchtrecht ingekorte uitspraak. Medisch Contact 2018: 34-37 Thijs RD, Surges R, O'Brien TJ, Sander JW (2019) Epilepsy in adults. Lancet. 2019 Feb 16;393(10172):689-701 Xu Z, Ayyappan S, Seneviratne U(2015) Sudden Unexpected Death in Epilepsy (SUDEP): what do patients think? Epil Behav 2015: 42:29-34.

\section{Hebt u de website van het Epilepsiefonds al bekeken? www.epilepsie.nl}

